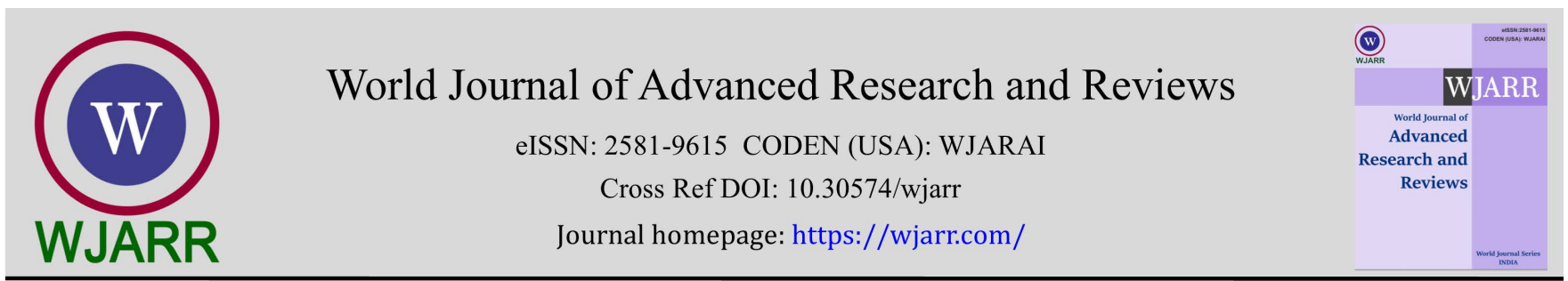

(RESEARCH ARTICLE)

Check for updates

\title{
Change of Mg concentration in several plants depending on plant species, washing status, and traffic density
}

\author{
Halil Baris Ozel 1, Hande Nur Varol 2 and Hakan Sevik ${ }^{3, *}$ \\ ${ }^{1}$ Bartin University; Faculty of Forestry; Forest Engineering Department, Bartin, Turkey \\ ${ }^{2}$ Bartin University; Graduate School; Forest Engineering Department, Bartin, Turkey \\ ${ }^{3}$ Kastamonu University; Faculty of Engineering and Architecture; Environmental Engineering Department, Kastamonu, \\ Turkey
}

World Journal of Advanced Research and Reviews, 2021, 12(01), 447-453

Publication history: Received on 21 September 2021; revised on 24 October 2021; accepted on 26 October 2021

Article DOI: https://doi.org/10.30574/wjarr.2021.12.1.0551

\begin{abstract}
Air pollution is one of the most important problems threatening the organic life and ecosystem throughout the world. Among the components of air pollution, the most important ones are the heavy metals that can be toxic and carcinogenic even at low concentrations and even the nutrient elements can be harmful when at high concentrations. Thus, monitoring the heavy metal pollution in the air is very important and plants are widely used as biomonitor for this purpose. However, which plants and organs are more suitable for monitoring which heavy metal pollution can be determined with detailed studies. In the present study, it was aimed to determine which plant species and which organ of that species would be more suitable for monitoring the concentration of magnesium (Mg) in air. For this purpose, five organs of five species grown in regions having different traffic densities were examined. In conclusion, it was found that Mg concentration in washed bark of Robinia pseudoacacia, wood of Platanus orientalis, washed leaves of Ulmus minor, and non-washed leaves of Acer negundo and Nerium olender increased with increasing traffic density.
\end{abstract}

Keywords: Air pollution; Heavy metal; Biomonitor; Magnesium; Mg

\section{Introduction}

Throughout the world, the most important problems of the current era are considered to be population growth [1, 2] and increasing population in urban areas [3-5], which refers to the urbanization [6-8], and consequently the other problems arising from these problems. Growing population and advancements in technology increase individuals' fundamental needs and need for comfort [9]. The production made in order to meet the sheltering [10,11] and nutrition [12] needs, which are the most important ones among increasing fundamental needs, causes excessive use of underground sources such as mineral deposits, besides the agricultural lands, forests, and waters throughout the world $[13,14]$.

Excessive use of these sources deteriorates the balance of ecosystem and the wastes arising from the production process cause excessive pollution in air [15, 16], water [17], and soil. Occurring as a result of this interconnected process, global climate change and urbanization are considered as the most important irreversible problems of today [18-21], while environmental pollution is accepted as the most important problem threatening the organic life and ecosystem [22, 23].

Environmental pollution is seen in urban areas at a higher level and the pollution arising from anthropological activities both deteriorates the balance of ecosystem and causes the death of millions of individuals annually. In particular, the

\footnotetext{
${ }^{*}$ Corresponding author: Hakan Sevik

Kastamonu University; Faculty of Engineering and Architecture; Environmental Engineering Department, Kastamonu, Turkey.

Copyright (C) 2021 Author(s) retain the copyright of this article. This article is published under the terms of the Creative Commons Attribution Liscense 4.0.
} 
air pollution has become a very severe problem such that the World Health Organization (WHO) reported that $90 \%$ of global population breathes polluted air [24]. Among the components of air pollution, heavy metals have a specific importance since they can be toxic and lethal even at low concentrations, they accumulate within the bodies of organisms, and even the elements that are necessary for organisms can be harmful when at high concentrations [25].

Thus, monitoring the heavy metal pollution in the air is very important. Since directly monitoring the change of heavy metal concentration in the atmosphere is very difficult and expensive, the method used for this purpose at most is the biomonitors $[26,27]$. In the present study, it was aimed to determine the most suitable biomonitor plant and its most suitable organ to be used for monitoring the heavy metal pollution in air and, for this purpose, the change of magnesium concentration by the traffic density was examined in leaves, branches, and woods of five different plant species.

\section{Material and methods}

The plants used in the present study were collected from the areas with different levels of traffic density, which is considered as one of the most important sources of heavy metal pollution $[28,29]$. For this purpose, the samples were collected from high-traffic (TRHigh), low-traffic (TRLow), and no-traffic (TRNo) regions. Within the scope of this study, leaf and branch samples were collected from Robinia pseudoacacia (RPse), Platanus orientalis (POri), Acer negundo (ANeg), Ulmus minor (UMin), and Nerium oleander (NOle) species and some of the samples were washed. Wood samples were then added into the analyses and Mg concentrations were determined in washed leaf (WaLF), non-washed leaf (UnWaLF), washed bark (WaB), non-washed bark (UNWaB), and wood (Wood) samples using ICP-OES device. The data obtained were subjected to variance analysis and Duncan test using SPSS 22.0 package software.

\section{Results}

Within the scope of this study, the change of $\mathrm{Mg}$ concentration by species and traffic density is presented in Table 1 .

Table 1 Change of $\mathrm{Mg}(\mathrm{ppm})$ concentration by species and traffic density

\begin{tabular}{|c|c|c|c|c|}
\hline TUR & TR No & TR Low & TR High & F Value \\
\hline RPse & 806,08 & $1104,56 \mathrm{~b}$ & $560,10 \mathrm{a}$ & $2,218 \mathrm{~ns}$ \\
\hline POri & 690,44 & $365,64 \mathrm{a}$ & $750,68 \mathrm{ab}$ & $1,736 \mathrm{~ns}$ \\
\hline ANeg & $1199,10 \mathrm{AB}$ & $1827,27 \mathrm{cB}$ & $1031,90 \mathrm{abcA}$ & $3,245^{*}$ \\
\hline UMin & 1021,86 & $571,32 \mathrm{ab}$ & $1177,86 \mathrm{bc}$ & $2,537 \mathrm{~ns}$ \\
\hline NOle & 1386,74 & $1736,02 \mathrm{c}$ & $1508,22 \mathrm{c}$ & $0,513 \mathrm{~ns}$ \\
\hline F Value & $1,851 \mathrm{~ns}$ & $9,519^{* * *}$ & $3,557^{*}$ & \\
\hline
\end{tabular}

Table 2 Change of $\mathrm{Mg}(\mathrm{ppm})$ concentration by organ and traffic density

\begin{tabular}{|l|l|l|l|l|}
\hline Organ & TR No & TR Low & TR High & F Value \\
\hline WaLF & $641,36 \mathrm{aA}$ & $2113,32 \mathrm{cB}$ & $492,68 \mathrm{aA}$ & $25,422^{* * *}$ \\
\hline UnWaLF & $1076,07 \mathrm{ab}$ & $943,29 \mathrm{ab}$ & $1717,37 \mathrm{c}$ & $2,574 \mathrm{~ns}$ \\
\hline $\mathrm{WaB}$ & $1423,37 \mathrm{~b}$ & $852,14 \mathrm{ab}$ & $1398,81 \mathrm{bc}$ & $2,774 \mathrm{~ns}$ \\
\hline UnWaB & $1381,09 \mathrm{~b}$ & $1275,91 \mathrm{~b}$ & $954,44 \mathrm{ab}$ & $1,050 \mathrm{~ns}$ \\
\hline Wood & $582,33 \mathrm{a}$ & $353,64 \mathrm{a}$ & $465,52 \mathrm{a}$ & $1,063 \mathrm{~ns}$ \\
\hline F Value & $4,055^{* *}$ & $9,104^{* * *}$ & $10,578^{* * *}$ & \\
\hline
\end{tabular}

As seen in Table 1, the change of $\mathrm{Mg}(\mathrm{ppm})$ concentration by traffic density was statistically significant at the confidence level of $95 \%(\mathrm{p}<0.05)$ only in ANeg and the lowest value was found in TRHigh and the highest value in TRlow. 
Considering from the aspect of species, the change of Mg concentration was statistically significant in TRLow and TRHigh. Moreover, the highest values in both densities were found in ANeg and NOle. The change of Mg concentration by organ and traffic density is presented in Table 2 .

Examining the change of Mg concentration by traffic density, it can be seen that the change by traffic density was statistically only in WaLF at the confidence level of $99.9 \%(\mathrm{p}<0.001)$. Moreover, the change of Mg concentration by organ was found to be statistically significant in all three traffic densities. The Duncan test results of wood in all three traffic densities were all in the first group. The change of $\mathrm{Mg}$ concentration by species and organ and the change by traffic density were analyzed together and presented in Table 3.

Table 3 Change of Mg (ppm) concentration by species, organ, and traffic density

\begin{tabular}{|c|c|c|c|c|c|}
\hline Species & Organ & TR No & TR Low & TR High & F Value \\
\hline \multirow{5}{*}{ RPse } & WaLF & $1342,90 \mathrm{jB}$ & 3200,66 tC & $230,26 \mathrm{dA}$ & $100193,392^{* * *}$ \\
\hline & UnWaLF & $1249,00 \mathrm{iC}$ & $910,80 \mathrm{iB}$ & $601,53 \mathrm{iA}$ & $10146,457^{* * *}$ \\
\hline & $\mathrm{WaB}$ & $541,33 \mathrm{dA}$ & $646,43 \mathrm{fB}$ & $1045,50 \mathrm{iC}$ & $1815,760^{* * *}$ \\
\hline & UnWaB & $652,53 \mathrm{eB}$ & $444,86 \mathrm{dA}$ & $668,80 \mathrm{kC}$ & $2595,024^{* * *}$ \\
\hline & Wood & $244,63 \mathrm{cA}$ & $320,06 \mathrm{cC}$ & $254,66 \mathrm{eB}$ & $451,076^{* * *}$ \\
\hline \multirow{5}{*}{ POri } & WaLF & $636,56 \mathrm{eB}$ & $1550,13 \mathrm{lC}$ & $103,20 \mathrm{bA}$ & $21088,397^{* * *}$ \\
\hline & UnWaLF & $1958,23 \mathrm{nC}$ & $53,16 \mathrm{aA}$ & $906,53 \mathrm{mB}$ & $94963,845^{* * *}$ \\
\hline & $\mathrm{WaB}$ & $264,93 \mathrm{cB}$ & $100,13 \mathrm{bA}$ & $547,20 \mathrm{hC}$ & $3917,458^{* * *}$ \\
\hline & UnWaB & $518,70 \mathrm{~dB}$ & $37,80 \mathrm{aA}$ & $595,66 \mathrm{iC}$ & $46231,126^{* * *}$ \\
\hline & Wood & $73,80 \mathrm{bA}$ & $87,00 \mathrm{bB}$ & $1600,83 \mathrm{pC}$ & $73858,343^{* * *}$ \\
\hline \multirow{5}{*}{ Aneg } & WaLF & $90,66 \mathrm{bA}$ & $3119,46 \mathrm{sC}$ & $1048,20 \mathrm{nB}$ & $316490,943^{* * *}$ \\
\hline & UnWaLF & $98,40 \mathrm{bA}$ & $1485,00 \mathrm{kB}$ & $1733,06 \mathrm{sC}$ & $29071,387^{* * *}$ \\
\hline & $\mathrm{WaB}$ & $1674,63 \mathrm{lB}$ & $1783,00 \mathrm{mC}$ & $913,83 \mathrm{~mA}$ & $249,019^{* * *}$ \\
\hline & UnWaB & $3137,73 \mathrm{rC}$ & 2281,56 oB & $1165,93 \mathrm{oA}$ & $5224,224^{* * *}$ \\
\hline & Wood & $994,06 \mathrm{fC}$ & $467,33 \mathrm{~dB}$ & $298,46 \mathrm{fA}$ & $24447,688^{* * *}$ \\
\hline \multirow{5}{*}{ UMin } & WaLF & $8,00 \mathrm{aA}$ & $667,30 \mathrm{fB}$ & $700,13 \mathrm{lC}$ & $3344,040^{* * *}$ \\
\hline & UnWaLF & $238,06 \mathrm{cB}$ & $54,80 \mathrm{aA}$ & $2124,80 \mathrm{uC}$ & $65068,868^{* * *}$ \\
\hline & $\mathrm{WaB}$ & 2203,8 oB & $996,3 \mathrm{jA}$ & $2411,40 \mathrm{vC}$ & $7750,207^{* * *}$ \\
\hline & UnWaB & $1580,23 \mathrm{kC}$ & $815,83 \mathrm{hB}$ & $627,33 \mathrm{jA}$ & $19509,552^{* * *}$ \\
\hline & Wood & $1079,20 \mathrm{fC}$ & $322,4 \mathrm{cB}$ & $25,63 \mathrm{aA}$ & $133389,477^{* * *}$ \\
\hline \multirow{5}{*}{ NOle } & WaLF & $1128,66 \mathrm{hB}$ & $2029,06 \mathrm{nC}$ & $381,60 \mathrm{gA}$ & $10888,579^{* * *}$ \\
\hline & UnWaLF & $1836,66 \mathrm{~mA}$ & $2754,4 \mathrm{rB}$ & 3220,93 yC & $9579,115^{* * *}$ \\
\hline & $\mathrm{WaB}$ & $2432,16 \mathrm{pC}$ & $734,86 \mathrm{gA}$ & $2076,13 \mathrm{tB}$ & $3100,088^{* * *}$ \\
\hline & UnWaB & $1016,26 \mathrm{fA}$ & $2590,40 \mathrm{pC}$ & $1714,46 \mathrm{rB}$ & $8926,529^{* * *}$ \\
\hline & Wood & $519,96 \mathrm{~dB}$ & $571,40 \mathrm{eC}$ & $148,0 \mathrm{cA}$ & $1905,449^{* * *}$ \\
\hline \multicolumn{2}{|c|}{ F Value } & $6250,101^{* * *}$ & $11266,967^{* * *}$ & $28159,296^{* * *}$ & \\
\hline
\end{tabular}

As seen in Table 3, the results obtained from variance analysis showed that the change in Mg concentration by species and organ and in all traffic densities were statistically significant at the confidence level of 99.9\%. Given the results presented in Table, it can be seen that Mg concentration increased with increasing traffic density in WaB organ of RPse species, Wood organ of POri species, UnWaLF organ of ANeg species, WaLF organ of UMin species, and UnWaLF organs of NOle species.

\section{Discussion}

Environmental pollution is one of the leading problems threatening the lives of organisms, including humans, and the balance of ecosystem throughout the world. The most important ones among the environmental pollutants are the 
heavy metals, which can remain in nature without any degradation for a long time, accumulate within the bodies of organisms, and be toxic or carcinogenic even at low concentrations [30]. Thus, it is very important to monitor the concentrations of heavy metals. Examined in the present study, $\mathrm{Mg}$ is a white mineral, which exists in soil in form of various compounds, is very light, and can burn with a white flame in air. In earth, it exits most widely in seas. Magnesium is one, maybe the most important one of 11 minerals, which have vital importance, together with calcium, phosphorus, ferrous, copper, chromium, iodine, and selenium. Since the body cannot create this mineral on its own, magnesium must be taken via nutrients. Chlorophyll of plants contains this mineral and it captures energy photons coming from the sun [31-33].

The magnesium in soil is used by plants and it can be called ferrous of the plant kingdom. Similar to the ferroushemoglobin duo in humans, magnesium enters into the chlorophyll structure in plants. The use of potassium and phosphor in animal manure depletes the magnesium and it alters the plants' magnesium intake capacity [31]. Magnesium is the center atom of chlorophyll and it plays a vital role in photosynthesis. Magnesium surplus prevents the intake of potassium and negatively affects the root development of trees [33].

In conclusion, it was determined in the present study that $\mathrm{Mg}$ concentration changed depending on the plant species and organ and the traffic density. Mossi (2018) reported the Mg concentration in plants, which were examined in that study, to vary between $4009 \mathrm{ppm}$ and $6557.5 \mathrm{ppm}$ and to increase depending on the traffic density. Mg is rarely examined as heavy metal in studies [34, 35] but more frequently as a plant nutrient [36]. However, the magnesium in soil and the magnesium in air should not be examined in the same category because there are few studies carried out on the potential harms of Mg intake through air to the human body and the studies reported that Mg concentration in air increased with increasing traffic density and $\mathrm{Mg}$ mineral deposits are the areas, which also include some other harmful heavy metals [37].

Heavy metal pollution is very important from many aspects and it concentrates generally in urban areas and industrial zones [38]. Increasing pollution threatens both organic life and ecosystem. For this reason, monitoring and reducing the heavy metal pollution in water, soil, and air is of vital importance. The heavy metal pollution in soil and water can be directly measured $[39,40]$. However, heavy metal pollution in air is generally monitored by using the biomonitors [41]. The heavy metal pollution in water can be reduced using various treatment methods [42], while the heavy metal pollution in soil can be reduced by using the polluted materials as raw material again [43] or by making use of plants (Cesur et al., 2021).

Plants play a major role in organic life and fulfill many ecologic, economic, and social functions in nature. The development and phenotypic characteristics of plants depend on genetic structure [44-46], edaphic factors such as soil structure and nutrient content [47-49], and climatic factors such as light, temperature, and precipitation [50-53].

Thus, the heavy metals in soil or air significantly influence the plant development. High concentrations of heavy metal in air or soil constitute a stress factor for the plants [54]. Stress factors such as aridity [55], frost [56], radiation [57, 58], and pollution [28] affect the structure of plants. Hence, high concentrations of heavy metals cause stress in plants and plants can accumulate the heavy metals from air, soil, and water in its body [59]. For this reason, plants can plan important roles in both monitoring and decreasing the heavy metal pollution. However, further comprehensive studies should be carried out in order to determine which plant should be more suitable for these purposes.

\section{Conclusion}

Air pollution is one of the most important problems of today's world. Using plants is considered as one of the most effective methods among the solution proposals. For as much, plants can reduce air pollution significantly. However, the impacts of different species on different pollution factors are also at different levels. Although a large number of plant species have been the subject of studies to date, these studies are not at a sufficient level yet. Therefore, it can be recommended to continue and diversify similar studies.

\section{Compliance with ethical standards}

\section{Acknowledgments}

We thanks to Bartin University, Faculty of Forestry and Kastamonu University, Faculty of Architecture and Engineering.

\section{Disclosure of conflict of interest}


The authors declare that they no conflict of interest. The none of the authors have any competing interests in the manuscript.

\section{References}

[1] Aricak B, Cetin M, Erdem R, Sevik H, Cometen H. The usability of Scotch pine (Pinus sylvestris) as a biomonitor for traffic-originated heavy metal concentrations in Turkey. Polish Journal of Environmental Studies. 2020; 29(2): 1051-1057.

[2] Koc I. Changes That May Occur in Temperature, Rain, and Climate Types Due to Global Climate Change: The Example of Düzce. Turkish Journal of Agriculture-Food Science and Technology. 2021; 9(8): 1545-1554.

[3] Ozturk S, Isinkaralar O, Yilmaz D, Cicek E. Tourists' Perspective Of Cultural Heritage Areas: ImportancePerformance Analysis Of Safranbolu. Research\&Reviews In Architecture, Planning and Design, Gece Akademi, Chapter. 2021; 7: 133-155.

[4] Öztürk S, Işınkaralar Ö, Yılmaz D. Restorasyon çalışmaları sonrası yerel halkın algı ve tutumları (Kayseri kalesi örneği). Doğu Coğrafya Dergisi. 2021; 26(45): 183-194.

[5] Öztürk S, Işınkaralar Ö, Yılmaz D, Çıllgınoğlu H. Bir Kültür Turizmi Destinasyonu Olarak Hasankeyf Örneğinde Ziyaretçi Memnuniyeti. Bartın Orman Fakültesi Dergisi. 2021; 23(2): 359-369.

[6] Kilicoglu C, Cetin M, Aricak B, Sevik H. Site selection by using the multi-criteria technique-a case study of Bafra, Turkey. Environmental Monitoring and Assessment. 2020; 192 (9): 1-12.

[7] Ozturk S, Isinkaralar O, Kesimoglu F. An Assessment on Shopping Centers as Consumption Places. KUJES. 2021; 7(1): 65-73.

[8] Öztürk S, Işınkaralar Ö, Yılmaz D, İhtiyar M. Koruma Yaklaşımı Olarak Tarihi Bir Güzergâhın Kültür Rotasına Dönüștürülmesi: Kastamonu Örneği, Turar Turizm ve Araştırma Dergisi. 2020; 29(2): 144-159.

[9] Kilicoglu C, Cetin M, Aricak B, Sevik H. Integrating multicriteria decision-making analysis for a GIS-based settlement area in the district of Atakum, Samsun, Turkey. Theor Appl Climatol. 2021; 143: 379-388.

[10] Bayraktar OY, Saglam-Citoglu G, Abo Aisha AES. The use of scrap tires in the construction sector. International Journal of Trend in Research and Development. 2019; 6(1): 253-256.

[11] Bayraktar OY, Saglam-Citoglu G, Abo Aisha AES. Performance Research of Lime Based Mortars. International Journal of Trend in Research and Development. 2019; 6(1): 257- 259.

[12] Sevik H, Cetin M, Ozel HB, Ozel S, Cetin IZ. Changes in heavy metal accumulation in some edible landscape plants depending on traffic density. Environmental monitoring and assessment. 2020; 192(2): 1-9.

[13] Aricak B, Cetin M, Erdem R, Sevik H, \& Cometen H. The change of some heavy metal concentrations in Scotch pine (Pinus sylvestris) depending on traffic density, organelle and washing. Applied Ecology and Environmental Research. 2019; 17(3): 6723-6734.

[14] Koc I. Using Cedrus atlantica's annual rings as a biomonitor in observing the changes of $\mathrm{Ni}$ and Co concentrations in the atmosphere, Environmental Science and Pollution Research. 2021.

[15] Türkyılmaz A, Şevik H, Işınkaralar K. Investigation of Heavy Metal Accumulation in the Black Pine Needles. Ecology Symposium 2018; 196: 11-13.

[16] Isinkaralar K. Removal of Formaldehyde and BTEX in Indoor Air Using Activated Carbon Produced from Horse Chestnut (Aesculus Hippocastanum L.) Shell. Ph.D. Thesis Hacettepe University Institute of Science Department of Environmental Engineering. Ankara, Turkey. 2020.

[17] Ucun Ozel H, Gemici BT, Gemici E, Ozel HB, Cetin M, Sevik H. Application of artificial neural networks to predict the heavy metal contamination in the Bartin River. Environmental Science and Pollution Research. 2020; 1-18.

[18] Bayraktar OY. The Use of Rice Husk Waste in Foam Concrete Production. Turkish Journal of Agriculture-Food Science and Technology. 2020; 8(12): 2716-2722.

[19] Varol T, Canturk U, Cetin M, Ozel HB, Sevik H. Impacts of climate change scenarios on European ash tree (Fraxinus excelsior L.) in Turkey. Forest Ecology and Management. Forest Ecology and Management. 2021; 491: $119-199$.

[20] Varol T, Ozel HB, Ertugrul M, Emir T, Tunay M, Cetin M, Sevik H. Prediction of soil-bearing capacity on forest roads by statistical approaches. Environmental monitoring and assessment. 2021; 193(8): 527. 
[21] Ertugrul M, Varol T, Ozel HB, Cetin M, Sevik H. Influence of climatic factor of changes in forest fire danger and fire season length in Turkey. Environmental Monitoring and Assessment. 2021; 193(1): 1-17.

[22] Koç İ. Küresel İklim Değişikliğinin Bolu'da Bazı İklim Parametreleri ve İklim Tiplerine Etkisi. Bartın Orman Fakültesi Dergisi. 2021; 23(2): 706-719.

[23] Ucun Ozel H, Ozel HB, Cetin M, Sevik H, Gemici BT, Varol T. Base alteration of some heavy metal concentrations on local and seasonal in Bartin River. Environmental monitoring and assessment. 2019; 191(9): 594.

[24] Elsunousi AAM, Sevik H, Cetin M, Ozel HB, Ucun Ozel H. Periodical and regional change of particulate matter and $\mathrm{CO}_{2}$ concentration in Misurata. Environ Monit Assess. 2021; 193: 707.

[25] Jo J, Jo B, Kim J, Kim S, Han W. Development of an iot-based indoor air quality monitoring platform. Journal of Sensors. 2020.

[26] Sevik H, Cetin M, Ozturk A, Ozel HB, Pinar B. Changes in Pb, Cr and $\mathrm{Cu}$ concentrations in some bioindicators depending on traffic density on the basis of species and organs. Applied Ecology and Environmental Research. 2019; 17(6): 12843-12857.

[27] Alaqouri HAA, Genc CO, Aricak B, Kuzmina N, Menshikov S, Cetin M. The possibility of using Scots pine needles as biomonitor in determination of heavy metal accumulation. Environmental Science and Pollution Research International. 2020.

[28] Karacocuk T, Sevik H, Isinkaralar K, Turkyilmaz A, Cetin M. The change of Cr and Mn concentrations in selected plants in Samsun city center depending on traffic density. Landscape Ecol Eng. 2021.

[29] Turkyilmaz A, Sevik H, Isinkaralar K, Cetin M. Use of tree rings as a bioindicator to observe atmospheric heavy metal deposition, Environmental Science and Pollution Research. 2019; 26(5): 5122-5130.

[30] Turkyilmaz A, Cetin M, Sevik H, Isinkaralar K, Saleh EAA. Variation of heavy metal accumulation in certain landscaping plants due to traffic density. Environment, Development and Sustainability. 2020; 22(3): $2385-2398$.

[31] Cetin M, Sevik H, Cobanoglu O. Ca, Cu, and Li in washed and unwashed specimens of needles, bark, and branches of the blue spruce (Picea pungens) in the city of Ankara. Environmental Science and Pollution Research. 2020; 110.

[32] Işılk Z, Görmüş S, Ergene N. Magnezyumun Klinik Önemi. Genel Tıp Derg. 2004; 14(2): 69-75.

[33] Boğa A. Ağır Metallerin Özellikleri ve Etki Yolları, Çukurova Üniversitesi Tıp Fakültesi, Fizyoloji Anabilim Dalı, Adana. 2007; 16: 218.

[34] Mossi MMM. Determination Of Heavy Metal Accumulation In Some Shrub Formed Landscape Plants, Kastamonu University Institute of Science Department of Forest Engineering, Phd Thesis. 2018; 141.

[35] Çavuşoğlu K, Gündoğan Y, Arıcı ŞÇ, Kırındı T. Mytilus sp (midye), gammarus sp (nehir tırnağı) ve cladophora sp (yeșil alg) örnekleri kullanılarak Kızılırmak nehrindeki ağır metal kirliliğin araştırılması. Balıkesir Üniversitesi Fen Bilimleri Enstitüsü Dergisi. 2016; 9(1): 52-60.

[36] Turkyilmaz A, Sevik H, Isinkaralar K, Cetin M. Using Acer platanoides annual rings to monitor the amount of heavy metals accumulated in air. Environ Monit Assess. 2018; 190: 578.

[37] Melek T. Evaluation of Some Soil Characteristics in Devrekani Agricultural Soil With The Help of Geographical Information Systems, Kastamonu University Graduate School of Natural and Applied Sciences Department of Sustainable Agriculture and Natural Plant Resources, MsC Thesis. 2020; 70.

[38] Alaqouri HAA, Ozer Genc C, Aricak B, Kuzmina N, Menshikov S, Cetin M. The Possibility of Using Scots Pine (Pinus sylvestris L.) Needles as Biomonitor in the Determination of Heavy Metal Accumulation Applied Ecology and Environmental Research. 2020; 18(2): 3713-3727.

[39] Çetin M, Şevik H, Türkyılmaz A, Işınkaralar K. Using Abies's needles as biomonitors of recent heavy metal accumulation. Kastamonu University Journal of Engineering and Sciences. 2021; 7(1): 1-6.

[40] Mutlu E, Uncumusaoğlu AA. Investigation of the water quality of Alpsarı Pond (Korgun-Çankırı). Turkish Journal of Fisheries and Aquatic Sciences. 2017; 17(6): 1231-1243.

[41] Yang Q, Li Z, Lu X, Duan Q, Huang L, Bi J. A review of soil heavy metal pollution from industrial and agricultural regions in China: Pollution and risk assessment. Science of the total environment. 2018; 642: 690-700. 
[42] Savas DS, Sevik H, Isinkaralar K, Turkyilmaz A, Cetin M. The potential of using Cedrus atlantica as a biomonitor in the concentrations of Cr and Mn. Environ Sci Pollut Res. 2021.

[43] Zhao P, Yao B, Meng J, Zhang R, Cao B, Li P. Studies on the fouling behavior and cleaning method of pervaporation desalination membranes for reclamation of reverse osmosis concentrated water. Separation and Purification Technology. 2021; 119034.

[44] Kaplan G, Gulcan A, Cagdas B, Bayraktar OY. The impact of recycled coarse aggregates obtained from waste concretes on lightweight pervious concrete properties. Environmental Science and Pollution Research. 2021; 28(14): 17369-17394.

[45] Yigit N, Sevik H, Cetin M, Gul L. Clonal variation in chemical wood characteristics in Hanönü (Kastamonu) Günlüburun black pine (Pinus nigra Arnold. subsp. Pallasiana (Lamb.) Holmboe) seed orchard. Journal of Sustainable Forestry. 2016; 35(7): 515-526.

[46] Hrivnák M, Paule L, Krajmerová D, Kulaç Ş, Şevik H, Turna İ, Tvauri I, Gömöry D. Genetic variation in Tertiary relics: The case of eastern-Mediterranean Abies (Pinaceae). Ecology and evolution. 2017; 7(23): 10018-10030.

[47] Imren E, Kurt R, Yucedag C, Bilir N, Ozel HB, Cetin M, Sevik H. Selection of Superior Clones By The MultiDimensional Decision Making Techniques in Scots Pine Seed Orchard, Journal of Forests. 2021; 8(1): 13-22.

[48] Cicek E, Tilki F, Kulac Ş, Yilmaz M, Yilmaz F. Survival and growth of three hardwood species (Fraxinus angustifolia, Ulmus laevis and U. minor) on a bottomland site with heavy clay soil. Journal of Plant Sciences. 2007; 2(2): 233237.

[49] Shults P, Nzokou P, Koc I. Nitrogen contributions of alley cropped Trifolium pratense may sustain short rotation woody crop yields on marginal lands. Nutrient Cycling in Agroecosystems. 2020; 117(2): 261-272.

[50] Ozel HB, Donduran V, Şevik H, Bilir N, Varol T. Investigation on sand-dune afforestation by Eucalyptus (Eucalyptus grandis W. Hill) in Patara-Antalya region. Theoretical and Applied Forestry. 2021; 1(1): 34-39.

[51] Ertugrul M, Ozel HB, Varol T, Cetin M, Sevik H. Investigation of the relationship between burned areas and climate factors in large forest fires in the Canakkale region. Environmental monitoring and assessment. 2019; 191(12): 737.

[52] Ozkazanc NK, Ozay E, Ozel HB, Cetin M, Sevik H. The habitat, ecological life conditions, and usage characteristics of the otter (Lutra lutra L. 1758) in the Balikdami Wildlife Development Area. Environmental Monitoring and Assessment. 2019; 191(11): 645.

[53] Ozel HB, Donduran B, Cakmakli E, Sevik H. Factors affecting success in natural regeneration works of cedar (Cedrus libani A. Rich.) In Kas region of Antalya. World Journal of Advanced Research and Reviews. 2020; 6(2): 054-059.

[54] Yigit N, Mutevelli Z, Sevik H, Onat SM, Ozel HB, Cetin M, Olgun C. Identification of Some Fiber Characteristics in Rosa sp. and Nerium oleander L. Wood Grown under Different Ecological Conditions. BioResources. 2021; 16(3): 5862-5874.

[55] Sevik H, Karaca U. Determining the resistances of some plant species to frost stress through ion leakage method. Feb-fresenius environmental bulletin. 2016; 25(8): 2745-2750.

[56] Sevik H, Cetin M. Effects of water stress on seed germination for select landscape plants. Polish Journal of Environmental Studies. 2015; 24(2): 689-693.

[57] Yildiz D, Nzokou P, Deligoz A, Koc I, Genc M. Chemical and physiological responses of four Turkish red pine (Pinus brutia Ten.) provenances to cold temperature treatments. European journal of forest research. 2014; 133(5): 809818.

[58] Ozel HB, Abo Aisha AES, Cetin M, Sevik H, Zeren Cetin I. The effects of increased exposure time to UV-B radiation on germination and seedling development of Anatolian black pine seeds. Environ Monit Assess. 2021; $193: 388$.

[59] Ozel HB, Cetin M, Sevik H, Varol T, Isik B, Yaman B. The effects of base station as an electromagnetic radiation source on flower and cone yield and germination percentage in Pinus brutia Ten. Biologia Futura. 2021.

[60] Shahid M, Dumat C, Khalida S, Schreck E, Xiong T, Nabeel NK. Foliar heavy metal uptake, toxicity and detoxification in plants: A comparison of foliar and root metal uptake. Journal of Hazardous Materials. 2017; 325 : 36-58. 